\title{
1 Shareholder value - conception and execution
}

[Michael Jensen \& William Meckling 1976] anticipated what was going to become the central corporate governance challenge of the 1980s: getting managers to pursue the interests of their shareholders by maximizing the value, and not the size or diversity, of their organizations.

Walkling (2008: 29)

"Shareholder value," a seemingly innocuous phrase, forms part of a prescriptive package that comes with significant political and ideological undercurrents. The rough-and-ready economic prescriptions Jensen \& Meckling (1976) handed out in their model of shareholder-value governance were taken up by Easterbrook \& Fischel (1991), who interpreted the ideas in the idiom of law. Together, the views of the foursome have shaped much of recent corporate theory. The shareholder-value model presents maximizing share prices as the overriding goal of corporate governance. The prescription has been influential in recent decades and continues to be so. It is responsible for much of the negative socioeconomic outcomes that have been experienced from the functioning of business corporations during this period.

Even some years before Easterbrook \& Fischel (1991), the influence of economic theory and maximizing shareholder value as the corporate goal was apparent in law. Robert Clark (1986), in his influential commentary on corporate law, mostly adopted the tenets of economic theory. Management's duty, according to Clark (1986: 17-18), is to "make corporate decisions so as to maximize the value of the company's shares." Significantly, Clark cited no authority in support of the proposition.

This chapter unbundles the shareholder-value package and places it in context. In the second part, the chapter explains how corporations have adopted maximizing shareholder value as their goal, and the tools and systems used in the endeavor. Total shareholder return (TSR), the metric that measures executive performance, focuses on the sum total of benefits that shareholders derive. With TSR as the instrument, corporations gear their leaderships to deliver shareholder value. 


\section{THE SHAREHOLDER-VALUE PACKAGE - AN} OUTLINE

The shareholder-value package rests on two legs. One is a seemingly limited notion that market-determined share prices are the best barometer of company management. This came, primarily, from Jensen \& Meckling (1976).

The other is a more doctrinaire position that explicitly rejects a role for law and public policy in corporate governance. Easterbrook \& Fischel (1991) advocated faith in the efficiency of markets and freedom for actors to make choices, untrammeled by legal restrictions or regulation. This offered the best guarantee for quality corporate governance and also promotes societal welfare. This variety of market fundamentalism, to paraphrase George Soros (1998), skirts some realities. For example, it does not account for the power imbalance in manager-subordinate relationships and the weakness of junior-level employees in corporate organizations - issues at the core of stagnant incomes for large sections of society and runaway rises in executive pay. Economic theory also ignores speculation in financial markets.

Proponents of shareholder-value governance represented the "law-and-economics" movement, which gained influence from the 1970s. Described by Kronman (1993: 166) as "the intellectual movement that has had the greatest influence on American academic law in the past quarter century," scholars in law-and-economics applied economic analysis to all phenomena - social, legal and political. They interpreted law in financial terms, focusing on its ability to promote "efficiency" or "wealth maximization," and save "transaction costs." Tools from the discipline of economics (Pareto efficiency or optimality and Kaldor-Hicks efficiency) were used to evaluate the impact of policies and regulations. Pareto efficiency, or Pareto optimality, is achieved when at least one person is economically benefited and none else is worse off. The Kaldor-Hicks model, on the other hand, accepts injury to some, provided the benefit to others is greater than the injury, and those benefiting can compensate the injured (Posner 2006).

\section{A Jensen \& Meckling (1976) - The "Agency Costs" Theory}

The economic theory of corporations Jensen \& Meckling (1976) presented focused on "ownership structure" and "agency costs." These phrases were included in the title of their work. The framework had shareholders as the owners of corporations and executives as shareholders' agents. Starting from here, the twin goals of governance would be to (a) check executives (agents) from appropriating shareholders' (principals') wealth, and (b) affirmatively 
increase shareholder wealth by incentivizing executives to deliver shareholder value.

\section{a Jensen \& Meckling's economic theory - an outline}

Jensen \& Meckling's economic theory of corporations had the following elements.

- A business corporation, or "firm" as Jensen \& Meckling termed it, is a "nexus of contracts." This presented the distinctive groups within corporations (shareholders, executives, workers and so on) in a competing mode, each jostling for its own advantage in a setting that is essentially adversarial. Qualities such as cooperation and teamwork that corporate enterprises heavily rely on, and on which corporate success largely depends, are excluded from the framework.

- The corporation is dismissed as a "legal fiction" that is of no consequence. With this, the framework in corporate law has no relevance. Directors, an important corporate group, find no mention in the theory.

- In the nexus-of-contracts framework, shareholders were the powerless group in corporations despite their nominal position as "owners." Other groups had the power to make or at least influence decisions - labor through unions, and consumers were free to make choices in the market for goods and services. From here, economic theorists took up the mantle for shareholders, who were projected as hapless.

- Shareholder inefficacy is taken as a given. As passive investors they either do not, or are unable to, effectively wield ownership rights through voting and the election of directors. Jensen \& Meckling's hypothetical model treated shares as nonvoting. In any case, voting rights did not matter much in the shareholder-value framework. The risk was that dissatisfied investors would sell their shares (or "vote with their feet") and this would trigger a slide in share prices - an outcome managers would endeavor to avoid. These realities, coupled with executive reward through stock options (discussed below), assured managers' loyalty to shareholders.

\footnotetext{
1 Ironically the nexus-of-contracts conception, seemingly egalitarian in spirit, was adopted to advocate a hierarchical corporate framework that stressed the ownership rights of shareholders and subordinated all other interests.

2 By the early $20^{\text {th }}$ century, a dominant stream of opinion considered shareholders as the "owners" of corporations. Milton Friedman's much-cited, and provocative, opinion editorial in The New York Times that the social responsibility of corporations is to maximize profits was based on the ownership position of shareholders (Friedman 1970).
} 
- The economic model retains the economic dimension of shares and stresses their entitlement to the corporate residue or surplus that remains after paying off debts and liabilities, while rejecting/ignoring the political dimension of shares that recognizes shareholders as the contributors of risk capital and empowers them with voting power.

- With shareholders as "owners," managers are placed in a nominally inferior position. The "agent-principal" rubric is used to interpret managers" equation with shareholders.

- Managers are perceived as risk-averse, reluctant to make bold decisions. Yet they often pursue unprofitable growth opportunities that erode shareholders' wealth and undermine corporate value.

- Managers also use up corporate resources, which rightfully belong to shareholders, to provide amenities for themselves and for purposes such as charity and philanthropy.

- Given these tendencies, a major concern of governance ought to be controlling "agency costs," which are the sum of managerial remuneration and the cost of monitoring managers to ensure they do not extract rents from corporations, thereby appropriating shareholders' wealth.

- To resolve "agency" problems and to assure managers' loyalty to shareholders, the interests of the two groups must be aligned. Granting stock options to managers and making them shareholders would be effective in achieving this goal. ${ }^{3}$ When managers become shareholders themselves, they will be incentivized to work for shareholder benefit and maximize share values. ${ }^{4}$

- Share buybacks are advocated as the preferable method of shareholder reward, over conventional dividends. An important advantage with share buybacks was that shareholders were taxed at a lower rate on gains made from buybacks. In advocating buybacks, Jensen (1986: 324) even recommended debt to fund share buybacks because the threat of bankruptcy from

3 Jensen \& Meckling's recommendation of the free use of stock options reflected the commoditization of shares - a process that was complete by the 1930s. This is far removed from the original conception of shares as units of capital meant for a corporation's enterprise or business project, a conception that carried substantial normative underpinnings. These issues are discussed in Chapter 6, which explains the "unleashing" of shares in law.

4 The method is morally ambiguous. The granting of stock options to executives on the basis that they would sell the resulting shares in the market, in effect, shifts the cost of rewarding executives to investors in the stock market. Corporations, as beneficiaries of executives' work, would externalize the cost of reward. Presumably, the underlying notion was that there would be no losers in a world of rising share prices. The reality has been quite different, as Chapter 2 shows. 
increased debt would be "an effective motivating force to make [corporations] more efficient."

Other than the above, economic theory does not prescribe any specific management structures, relative responsibilities of boards of directors and executive leaderships, or policies on business strategy, innovation, expansion or diversification. With shareholder value as the overarching principle, managers would presumably develop appropriate business strategies and governance structures, and handle operational issues in a manner that maximizes shareholder value. Stock options would be their incentive to deliver shareholder value.

Jensen and Meckling described their theory as positive (or descriptive), not normative. In other words, they looked at corporations as they were, without envisioning how they ought to be. Accordingly, they made no efforts to address or deal with the issues they targeted - namely, managerial power and shareholder vulnerability, in normative terms. Appropriate economic incentives would take care of the issues, QED.

However, Jensen \& Meckling's disavowal of normative goals is questionable. The argument that maximizing shareholder value ought to be the corporate goal was clearly normative. In advocating this, Jensen \& Meckling did wade into prescription to influence behavior - namely, granting stock options to managers to incentivize them to deliver shareholder value.

\section{b Economic theory - its background}

In presenting their theory on corporations, Jensen \& Meckling traced it to Adam Smith (1776), Berle \& Means (1932) and Ronald Coase (1937, 1960). Adam Smith, an early writer on "agency costs," complained that company directors would act in their self-interest and appropriate shareholders' wealth. Smith's framing of the issue reflected the principle of UK companies that treats shareholders as company owners and directors as their agents. By the early 20th century, shareholder primacy traveled across the Atlantic and it informed Berle \& Means' seminal work, The Modern Corporation and Private Property (1932). The title indicated the ascendancy of ideas about the ownership rights that had come to be attributed to shareholders. ${ }^{5}$

Jensen \& Meckling (1976) referred to corporations as "firms." Their apparent inspiration was Ronald Coase (1937) who used the term in developing his economic theory of corporate enterprises. Coase offered cost savings and resulting profit maximization as explanations for the workings of corporate

5 The shareholder position in North American corporations is fundamentally different. Importing the UK idea about their proprietary rights is quite inappropriate considering corporate history in the US and Canada. These issues are discussed in Chapter 5 . 
enterprises. In choosing between making a product and purchasing it from another source, a company would be guided by cost analysis. In its limited economic sense, the theory was quite accurate.

However, referring to corporations as firms is troublesome - and confusing. It ignores the legal organization of enterprises and the important consequences that follow. In law, the label "firm" is conventionally applied to partnerships that are aggregations of individual partners. Partnership firms are private arrangements at common law, created by contracts among partners. Corporations, on the other hand, are products of legislative sanction and are subject to mandatory rules that include election of directors by shareholders and statutory division of corporate powers among shareholders and directors. Corporations are not, and never were, merely enterprises run by the shared or joint efforts of several individuals.

More seriously, the "firm" is a conceptually inaccurate starting point for developing corporate theory. The working model Jensen \& Meckling (1976) presented had an individual entrepreneur starting out in business and then expanding by sale of equity, or ownership rights in the business, as the enterprise grew in size. Corporations, on the other hand, were engineered as vehicles for pooling capital to execute large projects that needed significant finance (see e.g. Davis 1917). They were/are created by the exercise of public power - originally through individual charters granted by states, later by complying with the procedure prescribed under general incorporation statutes.

Corporations always had a political dimension to them. ${ }^{6}$ Shareholders contributed the capital that was exposed to business risks, and had the right to (a) constitute corporate control by electing directors and (b) also the residue or surplus in corporations after paying off debts and liabilities. But corporate resources were off limits to shareholders unless corporations were in a position to service their liabilities. The law vested management powers in directors and permitted them to delegate powers to executives. To promote integrity and accountability, directors and executives were placed under fiduciary duties to corporations. To protect employees, directors were often made personally liable for unpaid wages. The position described continues to the present.

More contemporary trends, such as disclosures on board diversity (Canada) and pay equity ratio (US) underscore the continuity with the political side of business corporations. These are issues of economic and social justice. They rank among current concerns in the corporate discourse. The ongoing effort is to promote equity and fairness in the structure and functioning of corporations.

6 Law recognizes the two dimensions in corporations - commercial and quasi-political. In defining directors' functions, statutes generally refer to the "business and affairs" of corporations (see e.g. Model Business Corporation Act section 8.01). 
In engineering corporations as vehicles for pooling capital, the law thus places them in an orderly framework and subjects them to several mandatory rules. When an individual entrepreneur adopted the corporate form for doing business (as in Jensen \& Meckling's model), s/he would be equally subject to the rules and obligations. Jensen \& Meckling, however, chose to ignore the "corporation" dismissing it as a "legal fiction."

\section{c The corporation rejected - implications}

A number of factors can explain Jensen \& Meckling's dismissal of the corporation as a "legal fiction" that is of no consequence.

- The contemporary themes of managerial power in corporations (e.g. Baumol 1967, Marris 1967) and shareholder passivity (Berle \& Means 1932, Galbraith 1967).

- The reality of all-powerful CEOs portrayed by Mace (1971) and Nader et al. (1977).

The situation was underpinned by the minimalism corporate law had acquired by then and its so-called enabling character (Ballantine 1946). It made no meaningful efforts to regulate management power. The resulting position could, to some extent, justify Jensen \& Meckling's characterization of the corporation as an "insignificant legal fiction."

There was, however, more to the story. Acknowledging the corporation and its law could raise the question of legal reform to tackle problems in corporate governance. It risked having to wade into the debate on legal rules and their merits. But legal rules hardly mattered if economic incentives could solve all problems. For shareholder-value theorists, the only problems in corporate governance were the failure of corporations to deliver shareholder value and the steep agency costs that eroded shareholders' wealth. Jensen \& Meckling pitched for the use of financial incentives to cure these ills.

Anti-regulatory bias, an important element in the economic framework, did not come out openly in Jensen \& Meckling's agency costs theory presented in the mid-1970s. But the duo were vocal - and unequivocal - about their opposition to legal reform by the early 1980 s when the political climate was receptive to anti-regulatory rhetoric. Terming corporations "social inventions," Jensen \& Meckling (1982: 7) argued:

[The corporation] is neither the creature of the state nor the object of special privileges extended by the state. The corporation did not draw its first breath of life from either a minister of state or civil servant. More importantly, the corporation requires for its existence only freedom of contract. Corporate vitality in no way is dependent on special dispensation from the authorities. 
The contractarian assertion Jensen \& Meckling (1982) made is factually incorrect. Joint stock companies that emerged in the UK in the 18th and early 19th centuries were, in fact, private arrangements at common law. ${ }^{7}$ But corporations of the North American variety are conceptually different. They were always created through the exercise of public power, as products of laws enacted by elected assemblies representing the statement of public power. The position has been recognized at least since the early 17th century (Case of Sutton's Hospital 1612) that incorporation can only be attained from the exercise of sovereign (now, public) power. ${ }^{8}$ This position continues to the present.

To be clear, the debate on the character of corporations - as creatures of public power or private contract - would be unnecessary if economic prescriptions had produced better outcomes. The issue would be pedantic. But the results of economic theory are disappointing, as shown in Chapters 2 and 3. They include rising societal inequality, corporate expansionism aided by shareholder value and sub-diligent management culture.

\section{B Easterbrook \& Fischel (1991) - Legal Framework for Nexus of Contracts, and the Market Mantra}

Frank Easterbrook \& Daniel Fischel (1991), from the discipline of law, picked up the mantle of Jensen \& Meckling and presented in legal idiom the themes in economic theory. Greenfield (2006: 4) described the work of Easterbrook \& Fischel on corporations as "perhaps the most significant" since Berle \& Means (1932). Affirming shareholder wealth maximization as the legitimate corporate goal, Easterbrook \& Fischel (1991) asserted that it produced beneficial outcomes, overall - including for non-shareholder groups. They also offered additional perspectives on corporate theory (a) identifying a place for law in the framework, (b) articulating the nexus-of-contracts conception and (c) asserting the superiority of financial incentives and monetary penalties to structural changes in corporate governance.

7 The functioning of joint stock companies in the UK was found to be problematic. Endemic company failures and stock market scams forced regulation under the Joint Stock Companies Act 1844.

8 A related issue is about the element of discretion in the grant of incorporation, or incorporation as a privilege. With the rise of general incorporation, an argument was made that incorporation became a right. This is substantially true, but it is still a right granted by statute - one that could be revoked or put on terms. The issue this book raises is about the terms on which incorporation is granted. Considering the experience with business corporations, the argument presented here is for reviewing the terms and modifying them as appropriate for the present and the future. The public interest inherent in North American corporations makes this imperative. 


\section{a Economic theory and corporate law}

Jensen \& Meckling's agency costs theory, as noted, paid little attention to corporate law - the proverbial elephant in the room. Sidelining the corporation as an inconsequential legal fiction was quite inadequate. To be fair, by the late 20th century corporate law had lost many of its restrictive features. Yet corporate law and the newer breed of securities laws were, and remain, realities. To begin with, corporations are created under statutes. During their existence, they operate under a number of mandatory rules that include voting rights for shareholders and election of directors by shareholders, annual shareholder meetings and publication of periodic reports.

As legal scholars, Easterbrook \& Fischel (1991) could ill afford to ignore the law that creates corporations and governs them in their lifetime. To resolve the conundrum created by Jensen \& Meckling's simple rejection of the law, Easterbrook \& Fischel argued that the function of statute law was to provide a set of default rules that save "transaction costs" for market actors in forming corporations. By supplying several "default rules," statutes facilitate use of the corporate device and make it unnecessary for incorporators to write elaborate contracts to define each aspect of corporations. The argument supported the campaign to characterize business corporations as creatures of contract, or private arrangements at common law, and undermine the role of statutes in their creation.

Easterbrook \& Fischel's interpretation of statute law is inaccurate, quite removed from facts. For one, it does not satisfactorily explain why at all incorporation has always been under statutes and continues to be so. For another, it does not consider the development of corporate law since the 19th century. It was restrictive in the early 19th century but many of these earlier restrictions were removed or relaxed in the process of change that began in the closing decades of the century. The changes were dictated partly by the needs of the emerging industrial economy and partly from the influence of special interest groups. At any rate, there is no evidence that the changes made to corporate law were meant to improve "efficiency," as Easterbrook \& Fischel argued. These issues are discussed in Part II of this book.

\section{b "Nexus of contracts" articulated}

Expanding on the nexus-of-contracts conception, Easterbrook \& Fischel (1991) presented a framework that explained how corporations and the relationships of different groups within them (shareholders, executives, employees, customers and so forth) functioned by contracts, express or implied. The framework retained the nominally egalitarian principle by lumping together shareholders and non-shareholders, and interpreted the position of each group in the idiom of contract. The contractarian principle emphasized the freedom 
every group had to make choices, untrammeled by legal rules or restrictions that constrained behavior.

The contracts were sometimes negotiated and agreed upon, either directly between the parties or by the representatives of different groups - investment banks for shareholders, labor unions for employees and indenture trustees for bondholders. But this need not always be so. In many situations, company managers promulgated the terms and offered them on a "take-it-or-leave-it" basis. This, Easterbrook \& Fischel argued, was still contract because the other party had accepted the package in its entirety, as offered by managers.

The contractarian universe Easterbrook \& Fischel portrayed assumed effective freedom of choice for everyone, a rough equality of opportunities, and comparable bargaining strengths and negotiating skills in forming economic relationships. Regrettably, this utopia does not exist. The reality is quite different. Supposed equality and freedom of choice as the basis for developing behavioral norms and governance structures can inflict harm on weaker groups - for example, employees. Chapter 2 explains the increase in inequality in recent decades. Employment income crawled and large sections of society faced economic stagnation, alongside runaway increases in executive pay.

Jensen \& Meckling (1976) offered their nexus-of-contracts conception in the mid-1970s - verily, the high noon of American industrial supremacy. Organized labor was quite strong at the time and unions could effectively negotiate worker compensation packages. In this sense, the nexus-of-contracts framework reflected the reality that workers had a say in wage determination.

However, by the time Easterbrook \& Fischel elaborated the contractarian idea, more than a decade later, the picture had changed considerably. The takeover battles of the 1980s witnessed plant closings and mass redundancies, and the onset of globalization enabled corporations to move manufacture to low-cost countries, notably China. The developments weakened labor in the emerging equation. Despite this, Easterbrook \& Fischel (1991: 37) argued:

If employees negotiate for or accept a system of severance payments to protect their firm-specific human capital, they ought not [to] grumble if held to their bargains when business goes bad. (emphasis added)

It is not clear if the "negotiation" in the above equation would be handled by unions that can be more effective in bargaining with employers. Individual workers/job seekers are necessarily weaker in bargaining. Also the decline of labor unions (discussed in Chapter 8) is a reality and this further underscores workers' lack of effective negotiation power.

Easterbrook \& Fischel's reference to "or accepts" in the above statement acknowledges workers' weakness in negotiating employment terms. It is one thing for employees to be paid according to contractual terms (which, inci- 
dentally, are largely dictated by employers). The problem is when business does well, but corporate employers do not give employees a fair share in the rewards of success. This reality presented in Chapter 2 largely explains stagnant incomes for the bottom 80 percent of the society. It decisively undermines the contractarian hypothesis.

\section{c Shareholder wealth as "maximand" and its beneficial impact, overall}

Easterbrook \& Fischel (1991: 38) offered profit maximization as the ideal corporate objective or purpose. "Maximizing profits for equity investors," they argued, "assists the other 'constituencies' automatically." Stressing the complementarity between shareholders and other stakeholder groups and the "harmony of interests between profit maximization and other objectives," Easterbrook \& Fischel added, "Prosperity for stockholders, workers, and communities go hand in glove with better products for consumers" (ibid).

Experience shows that actual outcomes have been quite different from the predictions made. Data presented in Chapter 2 reveal that shareholders and executives have mostly appropriated the benefits of business growth and profits, paying little heed to the legitimate entitlement of stakeholders to fair treatment and a share in the rewards of success. Corporate policies and decisions are not guided by any notions about complementarity and harmony of interests among the constituencies. Profit maximization has encouraged, among other things, price markups for consumers, a failure to offer employees a fair share of the rewards of business success, and a lack of diligence in managing corporate responsibilities toward the environment and communities.

\section{d Financial penalties as guarantors of superior societal outcomes}

On the issue of social harm from corporate functioning - for example, pollution - Easterbrook \& Fischel argued in favor of financial penalties over rule changes to check profit-maximizing behavior. The approach retains profit maximization as the desideratum and subordinates all other considerations. Easterbrook \& Fischel (1982: 1168, n.36) wrote, "If illegality will benefit the company more than it will cost the company, the corporation should break the law."

The approach relies on cost-benefit analysis. If the benefits from polluting a river are greater than any cost it might impose in terms of penalties, corporations can persist with egregious behavior because there is a net benefit. The standard is clearly unacceptable as a societal norm. Legal taboos are value

9 For a critique of wealth maximization as a classical utilitarian principle, see Greenfield (2006). 
systems. Laws for protecting the environment are informed by social values, health concerns and even the species' survival instincts. A moral sense informs anti-bribery laws. Easterbook \& Fischel (1991: 39) rejected that pollution, racial equity and other "moral and social questions" qualify as governance matters. In other words, corporate governance is about profit and value maximization, and little else.

The problem with the approach is exemplified by General Electric (GE) in the 1990s. Bakan (2004) identified 42 "major legal breaches" GE committed during 1990-2001. These included breaches of environmental laws and worker and product safety, and defrauding the government in defense contracts. The company paid the penalties and moved on. Considering the pattern, there is little evidence of behavior modification let alone moral repentance. GE, apparently, treated the penalties as an (affordable) item in the cost of doing business.

To evaluate compliance with progressive laws and societal norms in purely economic terms, by applying a cost-benefit analysis, would be regressive. This can encourage unethical conduct in the pursuit of profits or value maximization. From the turn of the present century, there has been no dearth of corporate scandals. From fraud at Enron and WorldCom and manipulation of benchmark interest rates by international banks to Volkswagen's manipulation of software to conceal emission levels in its cars, there is sufficient evidence of corporate wrongdoing. The experience underscores the need for the inclusion of an ethical dimension in corporate governance.

\section{Economic Theory of Corporations, Human Behavior and the Ethical Dimension}

The economic theory of corporations confines itself to the economic aspect. It eschews other dimensions of issues that could be equally valid - social, political, moral or environmental - except to the extent they have financial implications and can be interpreted in financial terms. This analytic approach informs economic theory. In interpreting behavior, economic theory stresses the acquisitive and selfish (arguably, lower) traits in the human personality, and mostly ignores more noble qualities such as generosity, loyalty and compassion. Only economic incentives - in blunt terms, money - can persuade humans to act or refrain from acting.

The contractarian model in economic theory is, clearly, mono-dimensional and impoverished. It does not capture the rich and diverse factors - human qualities as well as expectations about the future - that impact contract negotiations and performance. It ignores the relational principle in contracts. Baker et al. (2002: 39) explained how "informal agreements and unwritten codes of conduct" mark relationships within organizations. In dealings among organizations, "long-run, hand-in-glove supplier relationships" help companies 
"reach accommodations when unforeseen or uncontracted-for events occur" (ibid). Regrettably, economic theory of corporations prefers to ignore these nuances in contractual relationships and presents rugged individualism and self-interest as the only factors.

By the 1990s, this economic theory of corporations had been put into practice. The shareholder-value mantra, agency ideas about executives and liberal use of stock options had become entrenched in the corporate landscape. Writing in this milieu, Brennan (1994: 34) offered a comprehensive critique of the dark vision of human nature that economic theory espouses.

The economic man lacks both virtue and (most) vice. While he is never resentful at being treated unfairly, he is never angry at the unfair treatment of others. While he is never discouraged by failure, he will never perform without incentives. While unerring in his pursuit of (suitably discounted) long-term gain, he has no honor or self-esteem, and feels no shame or pride in accomplishment.

Scandals at Enron, Global Crossing, Tyco and other companies at the turn of the 21 st century revealed the practical consequences of economic prescriptions. Executives' performance bonuses were linked to achieving earnings targets and the stock options granted to them as bonuses would vest on hitting the predefined earnings goals. Executives resorted to accounting fraud and reported false earnings so they could claim performance bonuses.

Ghoshal (2005) traced the trends to the cynicism underpinning economic prescriptions and its impact. Aside from "the criminal misconduct of managers in a few companies", Ghoshal (2005: 76) pointed out as a "far greater concern $\ldots$ the general delegitimization of companies as institutions and of management as a profession." He charged that this was "caused, at least in part, by the adoption of these ideas as taken-for-granted elements of management practice."

A major concern Brennan (1994) and Ghoshal (2005), both academics, had was about the consequences of preaching economic theory to students in management and finance. Brennan (1994: 39) cautioned:

[I]f we go on hammering into our students the mistaken notion that rationality is identical with self-interest, we shall gradually make our agency models come true, but at the cost of producing a society that will not function.

\section{Unbundling "Value" in Shareholder Value}

When Jensen \& Meckling (1976) presented their shareholder-value theory, it was somewhat a novelty. The idea was quite different from Coase's theorem on the "minimizing costs/maximizing profits" character of corporations a theory to which Jensen \& Meckling traced their lineage. In short, shareholder 
value is about share prices in the stock market. To make sense of the shift in emphasis to value, it is necessary to understand the background from which shareholder value emanated.

\section{a Shareholder value - context and stimulants}

Jensen \& Meckling (1976) did not clearly define or explain "value." But their meaning was apparent. It was the trading price of shares in the stock market. Jensen confirmed this in a 2008 panel discussion when he stated that, as a director of Armstrong World Industries, he had argued for using share price movements as the metric to measure management performance (Walkling 2008). ${ }^{10}$ Using share price changes as the yardstick to evaluate managements is rather strange because market prices of shares are something over which company managements have little direct control. In comparison, Coase's profit maximization theory appears more reasonable. Companies have greater control over their costs and can manage them more efficiently to increase profits.

The situation is different with share prices in the stock market. Companies have no direct control over the market prices of shares, and neither did Jensen \& Meckling (1976) recommend specific techniques or methods for corporations to boost share prices and deliver shareholder value. Equally important, any overt effort by companies to influence prices runs the risk of manipulation, which is prohibited under securities law. Yet the symbiotic relationship between corporations and the stock market is a fact. The following can be identified as factors that influenced Jensen \& Meckling (1976) to choose shareholder value as the normative goal for corporations.

- In the 1970s when Jensen \& Meckling presented their economic theory, American corporations were quite profitable. They also regularly paid dividends to shareholders. Dividend payments averaged 45 percent of companies' after-tax profits from the late 1960s through the 1970s (Feldstein $\&$ Green 1983). Therefore, neither corporate profitability nor shareholder reward were serious issues.

- Share prices, on the other hand, had remained flat for several years. Corporations had grown wealthier from business expansion and retained

10 A conceptual problem is apparent in the agency costs theory, as presented in the 1970s. In their hypothetical model, Jensen \& Meckling (1976) used a closely held corporation and stated they were unsure about the applicability of their model to listed corporations. Value would have little relevance in closely held corporations, since their shares are not traded on a daily basis. Nor do such enterprises get sold regularly or frequently. Value can only be relevant in listed corporations whose shares are traded in the stock market. 
earnings, but this was not reflected in share prices. There was no increase in share prices between 1966 and 1976; rather, there was a net decline in the eleven-year period. The Dow Jones Industrial Average fell from 969 at the end of 1966 to 859 in 1976, having peaked at 1,044 in 1973, as shown in Figure 1.1. As a result, shareholders drew no benefit by way of value appreciation for shares, despite corporate growth and the increase in wealth that corporations commanded.

- An early instance of companies' efforts to stimulate increases in share prices was visible in the Conglomerate Boom of the 1960s (Soros 1987). The acquisition spree that came to be termed the Conglomerate Boom saw corporations acquire other companies, often in very different lines of business, and they become "conglomerates" with diverse operations. An example was International Telephone \& Telegraph (now ITT Inc) acquiring Sheraton Hotels and Wonder Bread. The stock market tended to reward companies that reported growth in earnings with higher share valuations. And this was a major incentive for the Conglomerate Boom. Companies with higher earnings per share (EPS) were sought-after targets because acquiring them boosted the combined EPS of merged companies. The reward was higher share prices. Acquisitions thus offered a pathway to stimulate a rise in share price and deliver shareholder value.

Against the background described, Jensen \& Meckling advocated shareholder value as the corporate goal. Clearly, it was an idea whose time had come. From

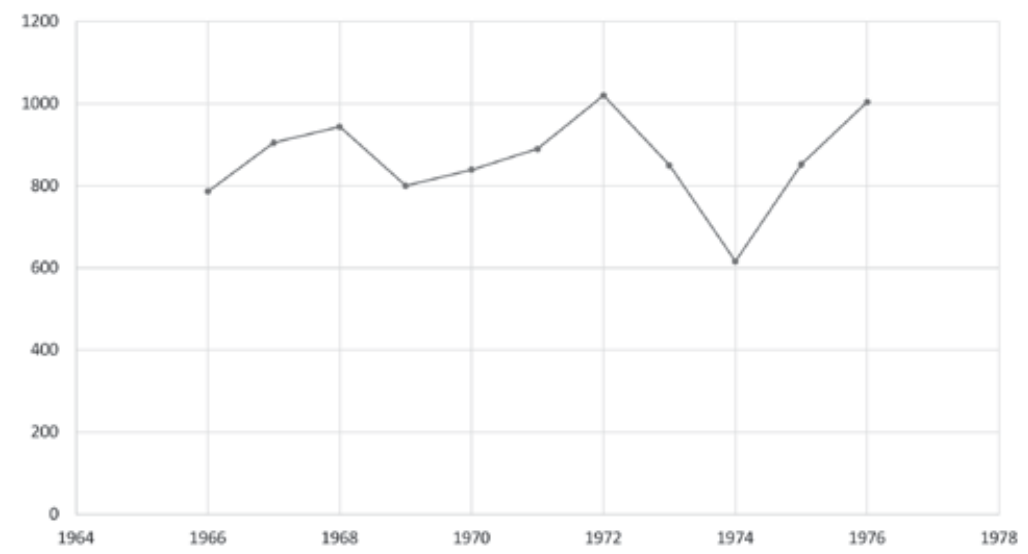

Figure 1.1 Dow Jones Industrial Average - closing values, 1966-1976 


\begin{tabular}{lccc}
\hline & 2016 & 2015 & \% Change \\
\hline Number of Pension Plans & & & \\
All Plans & 702,540 & 693,925 & 1.2 \\
DB Plans & 46,300 & 45,672 & 1.4 \\
DC Plans & 656,241 & 648,252 & 1.2 \\
401(k) Type Plans & 560,373 & 546,896 & 2.5 \\
Assets (US\$ trillions) & & & \\
All Plans & 8.61 & 8.15 & 5.6 \\
DB Plans & 2.92 & 2.86 & 2.1 \\
DC Plans & 5.69 & 5.29 & 7.6 \\
Plan Contributions (US\$ billions) & & & \\
All Plans & 584.4 & 543.2 & 7.6 \\
DB Contributions & 125.5 & 108.6 & 15.6 \\
DC Contributions & 459.0 & 434.6 & 5.6 \\
\hline
\end{tabular}

its presentation in the mid-1970s, major macro trends in the following years aided the growth of the shareholder-value paradigm. The trends included:

- The introduction of 401(k) pension savings plans in 1978, leading to a constant, ever-increasing flow of funds into the stock market, contributing to a general rise in share values.

- The shareholder-value/stock-options model being embraced by (a) company leaderships and (b) the investment industry, both of which directly benefit from higher share prices.

- Globalization taking off from the 1980s, giving companies the ability to reduce costs by offshoring manufacture and business processes to low-cost countries.

- Changes in the financial economy and increased liquidity boosting trade volumes in the stock market and thereby share prices. ${ }^{11}$

Pension savings inflows into the financial markets have been massive. A representative sample is available in the following data (Table 1.1) on US private pension plans in recent years (US DOL 2018: 2).

11 See e.g. Paul Singer, head of Elliott Management hedge fund, who was critical of the "easy money" policies of the Federal Reserve. Singer complained that it makes the wealthy wealthier. He termed the Federal Reserve "enablers" of deepening inequality in the United States (cited in de la Merced 2014). 
Just in the two years covered in the table, pension contributions totaled almost US\$ 1.13 trillion, with a year-on-year increase of 7.6 percent. If US public sector pension investments and Canadian pension investments are also considered, the numbers will be much higher both for inflows into the markets and common stock holdings by pension funds. ${ }^{12}$ The trends have contributed to rising share prices since the 1980s and higher share prices seemed to affirm the shareholder-value model. Corporate executives and the investment industry that both benefit from rising share prices drove the system, and this made the cycle self-reinforcing. Consequences for the rest of the society are, however, a different story. This is the subject of the next chapter.

\section{b Market pricing of shares and the "science" of shareholder value}

The economic theory of corporations is closely aligned with the efficiency theory about financial markets. Just as free market arrangements are supposed to produce optimal governance outcomes, financial markets with their efficiency are offered as the best instrument for setting trading prices for shares. In presenting share price maximization as the goal, the economic theory of corporations found a natural ally in the efficient markets hypothesis that commends the ways of the stock market.

Economic theory treats share prices as something endogenous to financial markets. The approach is quite removed from the conception of shares in classical corporate law as units of the capital raised for projects or other business needs. In that structure, shares as units of the capital fund had fixed par values. ${ }^{13}$ This was the clear principle of the rules governing the issue of shares by companies to investors, to raise capital. This is generally termed the primary market for shares.

The situation has generally been quite different in the secondary markets where shares are traded. In this segment, flux in prices is standard with movements dictated by demand/supply for the shares of specific companies influenced by the information available about the companies and expectations about the future, all operating in an innate climate of speculation. Price volatility has been a general feature in the secondary market.

In the background described, Graham \& Dodd (1934) advocated a more calculated approach to secondary market investing, distinguishing it from speculation. This involved examining the earnings of the companies and div-

12 In terms of impact, the total number of participants and beneficiaries of deceased participants was over 138 million for the private sector pension plans (US DOL 2018).

13 Changes in the rules between the 1880 s and 1920 s effectively "unshackled" shares and this played an important role in the rise of the shareholder-value/ stock-options paradigm of corporate governance. The changes made to legal rules and their normative significance are discussed in Chapter 6. 
idend income from shares. Written in the midst of the Great Depression, the method was well received.

In the following decades, however, a period of relative lull in the financial markets, the calculative approach advocated by Graham \& Dodd (1934) gave way to the efficient markets hypothesis. In the efficient market framework, the price of a company's shares is determined on the basis of (a) information available about the company and (b) expectations about future price (Fama 1965). Around this time, Adolf Berle (1968) was writing that the stock market appeared to have exhausted its function as a forum to provide companies the capital they needed for their business. It had mostly become a platform for trade in shares, and its principal function was providing liquidity to investors. Berle, it is pointed out in the next chapter, also reflected the idea that rising share prices would lead to all-round prosperity in society.

The approach formalized a definitive shift in the function of shares and the stock market. Shares were no longer just units of capital a company raised for funding business needs and the stock market was not simply a forum for trade in shares to provide liquidity for investors to exit without disrupting the capital of companies. Shares had a life and value of their own, and the stock market was a forum where they were constantly traded, hopefully at increasingly higher prices that bestowed prosperity all around. ${ }^{14}$

Reflecting these ideas, Easterbrook \& Fischel (1991: 18) explained price discovery in the stock market in the following terms:

The price of stocks traded in public markets is established by professional investors, not by amateurs. These professionals - market makers, arbitrage departments of investment banks, managers of mutual funds and pension trusts, and others - handle huge sums that they are willing to use to purchase undervalued stocks. They study the firm's profits and prospectus and bid or sell accordingly.

14 The idea that constant trade in shares can itself be a source of revenue has been carried to its logical conclusion through devices such as high-frequency trading and algorithmic trading. They were the subject of Michael Lewis' Flash Boys: A Wall Street Revolt (2014). Reflecting the prevailing mood that is supportive of financial speculation, Joseph Stiglitz was excluded from an advisory panel on high-frequency trading that the US Securities and Exchange Commission proposed to set up, because of his opposition to the trading method (Michaels 2015). The efficacy of tech-enabled trading is evident from the success of James Simons, reportedly the second wealthiest hedge fund manager in 2017 after George Soros. Simons' estimated net worth was US\$ 18 billion (Vardi 2017). A mathematician by training and described as a quantitative trading genius, Simons founded Renaissance Technology Corp in 1982, the time when technology was entering trade operations in the financial markets. Combining technology with math skills, Simons attained great financial success. 
According to the theory, price gets adjusted through constant transactions of purchase and sale in the shares of individual companies driven by expectations about the future. The description, written in approving terms, confers legitimacy on the price discovery process in the market and, by implication, on the resulting prices of shares. It is in accord with the thesis of Fama (1965) that trading prices of shares reflect their intrinsic value.

The approach neatly avoids the entire issue about speculation, or the "casino" element in the stock market. A longstanding feature, it drew much criticism in the 19th century (see generally Banner 1998). In recent times, however, with the efficient markets hypothesis gaining influence in an environment of rising share prices, speculation as a feature of the stock market has seemingly lost prominence. Criticisms of speculation have produced little effect.

Robert Shiller (2000) presented a very different picture of share pricing - one that considered speculation in the market. ${ }^{15}$ During the Internet boom of the 1990s, Shiller's Irrational Exuberance offered a critical perspective. Describing the price determination process for common shares in the stock market, Shiller (2000: 203) wrote:

The market level does not, as so many imagine, represent the consensus judgment of experts who have carefully weighed the long-term evidence. The market is high because of the combined effect of indifferent thinking by millions of people, very few of whom feel the need to perform careful research ... and who are motivated substantially by their own emotions, random attentions, and perceptions of conventional wisdom.

The portrayal by Shiller matched, almost word for word, a description of the ways of the London market in the late 19th century. Giffen (1877: 162-163) complained about the "utter unreasonableness of many of the public about securities" and the "diffused insanity" of the public. Giffen also bemoaned the deleterious impact of "City editors and other experts, or supposed experts [who] are followed in their slightest hints of opinion."16

Speculation in the stock market is a longstanding feature. Yet efficient market theorists effectively ignored this feature of the market, the resulting

15 Fama (1965) and Shiller (2000) presented opposite versions of the stock market and share prices. While Fama ignored speculation and interpreted market trends in the idiom of efficiency, Shiller underscored the element of speculation in the trade in shares. In a seeming display of even-handedness, the Nobel Prize committee awarded both of them the Nobel Prize in 2013.

16 Shiller (2000) and Giffen (1877) are aligned to behavioral economics, which adopts a more complete vision of human nature and decision making, including quirks and biases. It highlights the limitations of the rational and evaluative qualities on which much of economic theory is based. 
instability in share prices and their consequences. Possible explanations could be the absence of significant market turbulence in the post-World War II decades, during which the theories about efficient markets were developed, and the theorists' neglect of longer time horizons. After all, the 1930s was the era of the Great Depression initiated by the Great Crash of 1929 on Wall Street. These were very much within living memory, but find no place in the efficient markets theory. Yet another possibility for excluding speculation from the framework is the theorists' refusal to consider facts that did not fit in with their narrative about the efficiency of markets. In any case, the omission underscores the need for more wholesome approaches and longer time horizons in developing theories on important subjects such as business corporations and the stock market.

In the years since Shiller's Irrational Exuberance, Mitchell (2008) and Martin (2011) have criticized the acceptance of the speculation-driven shareholder-value model of governance. ${ }^{17} \mathrm{~A}$ critical voice against speculation from within the investment industry was Laurence Fink, founder of BlackRock, the world's largest asset manager. Fink (2015), understandably, avoided direct criticism of financial markets. Yet he placed the phenomenon in the context of larger social, economic and political trends, and lamented the creation of "a gambling culture in which we turn out everything except the most immediate outcomes" and cautioned against getting mesmerized by "the lure of fleeting gains." Regardless, the sway of shareholder value is powerful as the following discussion shows.

\section{SHAREHOLDER VALUE - ADOPTION, INSTITUTIONALIZATION AND METHODS}

\section{A Early Stages}

The shareholder value advocated by Jensen \& Meckling (1976) found ready traction in corporate governance. Its influence has been evident for over two decades. By the 1990s, companies routinely stated their goal in the shareholder-value idiom. Porter (1997: 10) observed:

Maximizing "shareholder value" as measured by current stock price is explicitly codified in many companies as the corporate goal ... The goals set by American managers are typically framed in terms of ROI (Return on Investment) or increasing stock price.

17 Stout (2012) provided another strong critique of shareholder-value model of governance. 
By the late 1990s, notions about shareholder value had taken root in Canada as well. Takeover bid cases fought during the time evidence the development. Referring to a directors' circular issued in response to a hostile bid, the court noted in CW Shareholdings $v$ WIC (1998) the directors' "stated intention in the circumstances [was] to maximize near term value for the shareholders," and the directors "considered themselves to be under a legal duty to do so." In Maple Leaf Foods Inc v Schneider (1998), the Ontario Court of Appeal noted that the actions of the directors of the target company were guided by the notion that maximizing shareholder value was the appropriate goal or criterion in dealing with the hostile takeover bid that had been launched.

Documenting shareholder value as the corporate goal institutionalized the model. The logical next step was to develop mechanisms to motivate executives to attain the goal. The methods have evolved over time.

\section{a Incentivizing executives}

To get executives to deliver shareholder value, economic theory prescribed incentives. The method was to award a performance bonus to executives, linking it to shareholder value. Bonuses would be in the form of stock options, rather than cash. The method had twin advantages. One, it "aligned" executives' interests with shareholders. With stock options, executives also become shareholders and this would prod them to work for shareholder value. Two, it would also save companies money as there would be no cash payments. ${ }^{18}$

EPS, as noted, are a major tool in stimulating share price increases. EPS growth is warmly received in the stock market and companies that report healthy growth in EPS are rewarded with higher share valuations. If EPS growth could deliver shareholder value, it would be logical for companies to offer incentives to executives to work for an increase in earnings. Setting earnings targets for the award of bonuses emerged as standard corporate practice. Edward Chancellor (2002) wrote of the 1990s:

During the bubble period, the market tended to reward companies which managed to supply annual per-share earnings growth of $15 \%$ - a magic number chosen, it would seem, because it implied profits would double over five years. In the real

18 As pointed out earlier, bonuses in the form of stock options "externalizes" executive compensation. It shifts the cost of executive bonuses to investors in the stock market, who will pay the price when executives sell their shares in the market. This can be troubling from an ethical perspective, but economic theory apparently had little concern for such issues. Indeed, cash savings in awarding bonuses in stock options were presented as a major advantage for companies. More recently, companies reportedly pay cash to executives to purchase shares issued upon exercise of stock options (Sender 2015). 
world, in a period of low inflation, this was an absurd target. Nevertheless, it became commonplace.

\section{b Earnings targets, executive bonuses and their perils}

The problems with the shareholder-value model and its tools surfaced quite soon. To earn bonuses, executives had to meet earnings targets. Chancellor (2002) pointed out that executives used several means to meet their earnings-growth targets. The methods included:

- Reporting unofficial and unaudited earnings (termed "pro forma"), ignoring certain costs such as depreciation.

- Boosting growth in EPS by taking on debt to repurchase shares.

- Reducing normal and necessary business expenses (e.g. investment in research and development or marketing), to project sustained earnings growth.

- Bolstering earnings by acquiring other companies, whose shares were less highly valued (with GE and Tyco cited as examples).

The corporate scandals at the turn of the 21 st century demonstrated the consequences of the model. Enron offers a classic, if tragic, illustration of companies trying to stimulate share price increases through EPS growth and offering bonuses to executives to hit the targets set for earnings growth. Enron was a poster child of shareholder value. ${ }^{19}$

The compensation structure for Enron executives, inspired by shareholder value, was instrumental in the fraud committed in the company leading to its ultimate collapse. In the last years of Enron, the arrangement had turned almost completely share price-centric (Vasudev 2008). The employment contract of Kenneth Lay, Chair/CEO of Enron, as amended in 1994 linked his bonus to EPS growth. The employment contract included the EPS targets in dollars and cents that had to be met for Lay to qualify for a bonus. With suspicious accuracy, Enron presented results that were right on target with the EPS numbers. Earnings targets set for Kenneth Lay rose at 15 percent annually, substantiating the corporate practice Chancellor (2002) reported.

Lay's final contract, executed in 1999, went further (Vasudev 2008). It tied Lay's bonus to a rise in Enron's share price in comparison to rises in the S\&P Index. In other words, to earn his bonus, Lay's task was to get Enron shares to outperform the S\&P index. EPS growth, the measure of performance used

19 Enron: The Smartest Guys in the Room (2005), a documentary film on Enron, shows the company chair Kenneth Lay casually mentioning in a public meeting that share prices had just doubled and adding they would double again in the next year to 18 months. 
in the earlier contract, was also financial. But earnings as the measure at least focused on the business of the corporation and offered bonuses for achieving business growth through higher earnings.

The transition from EPS to relative performance of share prices in the stock market as the criterion for executive bonuses changed the dynamic further. It strengthened executives' concern with share prices, correspondingly undermining attention to the core business of companies. Executives would now focus on engineering share price increases. In this universe, the business of the corporation would be secondary. Shareholder value reigned supreme, subordinating everything else.

Enron, WorldCom and other scandals that broke in the early 2000s were eye openers. To meet earnings-growth targets on which shareholder value and executive bonuses depended, many companies infamously manipulated their financial reports. They hid losses and reported false earnings. When this came to light, some collapsed in the wake of the scandal that followed. The failure of the companies inflicted losses all around - on shareholders as well as other stakeholders. The fraud at Enron and WorldCom that led to their demise and the incentives that were at work - executive bonuses linked to financial metrics - underscored the perils of share price obsession.

Shortly after the Enron scandal broke, Michael Jensen laid the blame on analysts for setting unrealistic targets for managers (Fuller \& Jensen 2002). The criticism is questionable. It overlooked that in Enron and other companies, the ongoing effort of executives was to meet earnings targets set in employment contracts so they could receive the performance bonuses.

At any rate, the corporate scandals and failures did not seriously impair the shareholder-value model of governance. Old methods have continued, more or less. As shown a little later, the methods Enron adopted have become standard.

In what appears to be a lone voice in the crowd, MEDAC, a Quebec institutional investor, questioned linking executive stock options to share price movements. MEDAC's shareholder proposal presented to the Canadian Imperial Bank of Commerce (CIBC) in 2012 argued that "companies' stock performance is influenced by many factors beyond the control of senior executives, such as interest rates or inflation" (MEDAC 2012). The effort was futile, with just 4 percent of shareholders voting in favor of the proposal. The practice of incentivizing executives to work for shareholder value continues, as the following discussion shows.

\section{B Trends in the Post-Enron World}

Post-Enron, the term "short-termism" entered the corporate governance discourse. The phrase refers to corporate focus on quarterly results, driven by the shareholder-value model of governance. There have been several influential 
critiques of preoccupation with quarterly earnings and share prices. Yet there is little meaningful change, as evident from the following discussion.

\section{a Critiques of short-termism}

Influential institutions and business leaders launched movements that stress long-term thinking in corporate governance. Conference Board, the influential business association, published "Revisiting Stock Market Short-Termism" (Tonello 2006). Among corporate leaders, Lou Gerstner, former IBM Chair and CEO of IBM credited with reinventing the company and saving it from a meltdown, articulated the harm from short-term approaches. Gerstner (2014) explained how analysts' preoccupation with quarterly earnings could inflict damage on companies' long-term prospects:

Who says the analysts are right when they mark down a company's stock just because it makes 89 cents in the first quarter rather than the 93 forecast by the market? Are they thinking about the long-term competitiveness of the company? Are they thinking this would have been a good time to reinvest, or are they just churning out numbers and saying they want earnings per share to go up every quarter? This kind of short-term pressure on current earnings can lead to underinvestment in the long-term competitiveness of a business.

Several ongoing initiatives endeavor to promote long-term perspectives in corporate governance. These include:

- The Business and Society Program at the Aspen Institute, which fosters networks and working groups with the goal of "aligning business with the long-term health of society.” (Aspen Society 2019)

- Focusing Capital on the Long Term (FCLT) Group, which has major business leaders and the Canada Pension Plan Investment Board among its sponsors, "works to encourage a longer-term focus in business and investment decision-making ... by developing practical tools and real-world approaches that encourage such behaviors." (FCLT 2019)

Another development is the formulation of enlightened shareholder value (ESV). The ESV model retains benefit for companies (and thereby, shareholders) as the desideratum, but encourages long-term focus and exhorts managements to consider stakeholder interests (employees, suppliers and communities and so on) in decision-making and governance. This approach is considered more effective in fostering companies' long-term growth and delivering sustainable value for shareholders. To state the obvious, ESV is still about shareholders and treats their benefit as supreme. In advocating shareholder 
benefit, ESV considers non-shareholder interests also because this approach better assures the long-term interests of companies and their growth. ${ }^{20}$

In sum, in the so-called post-Enron World, on one hand, there is the doctrinal recognition of the perils of short-termism and of the need for long-term focus, including ESV. However, on the other hand, their adoption in corporate practice is questionable. Recent evidence on executive compensation and bonus plans indicates the continuing influence of shareholder value with little change.

\section{b TSR and long-term incentive plans (LTIP)}

To state the obvious, incentives are critical determinants of corporate policies and the decisions that managements make. The evidence is that the system continues to affirm shareholder value. Early on, as noted, shareholder value was mostly understood as stimulating increases in share prices in the stock market (see e.g. Porter 1997). Over time, the concept has expanded and become more sweeping. Presently, shareholder value formalized as TSR is described as follows:

Total Shareholder Return (TSR) factors in capital gains and dividends when measuring the total return generated by a stock to an investor. TSR is the internal rate of return (IRR) of all cash flows to an investor during the holding period of an investment. Whichever way it is calculated, TSR means the same thing: the total amount returned to investors. (Investopedia 2019)

In the above definition, dividends include share buybacks. This is logical because buybacks, like dividends, require use of corporate cash and involve payouts to shareholders. A relatively new and important element in shareholder reward, buybacks are the practice of companies purchasing their own shares from investors. Together, the three elements - share price increases, share buybacks and dividends - constitute TSR, which is the current and formal version of shareholder value.

As TSR, shareholder value has two dimensions - internal and external. The internal dimension is about direct use of corporate resources for shareholder benefit, through payouts in the form of dividends or share buybacks. Externally, it is about stimulating demand for a company's shares in the stock market and thereby boosting the trading price of shares. To deliver shareholder value in this external aspect - namely, stock market impact - a number of tools can be used. These include reporting consistent business growth (sales,

20 Enlightened shareholder value is an idea in UK company law dating back to the 19th century (Hutton $v$ West Cork Railway 1883). ESV is now codified in the UK Companies Act 2006. 
Table 1.2 Performance metrics in bonus plans, 2015

\begin{tabular}{lcc}
\hline \multicolumn{1}{c}{ Performance Metric } & Canada S\&P/TSX Composite & US S\&P 500 \\
\cline { 2 - 3 } & Percent & Percent \\
\hline Relative TSR & 37.5 & 45.6 \\
Absolute TSR & 5.4 & 5.2 \\
Return on Capital & 11.9 & 22.8 \\
EPS & 9.2 & 23.6 \\
Other Non-Financial & 5.4 & \\
Cash Flow & 4.9 & 9.6 \\
Cost/Cost Ratio & 4.9 & \\
Revenue & 4.3 & 18 \\
EBITDA & 4.3 & 6.4 \\
Operating Income/Margin & & 14.4 \\
Net Income & & 5.6 \\
\hline
\end{tabular}

profits), improving visibility through a variety of means (brand building for products/services, announcing growth plans, product innovations, social initiatives and the like), and efficient management of relationships with the investment industry. The possibilities are many and varied. Together, effective use of an appropriate combination of tools can produce the best results.

Shareholder value, formalized as TSR, requires companies to deliver value to shareholders on both fronts - internal and external. Corporate managements are measured by how they directly reward shareholders through payouts and also how they manage their share prices. This is, more or less, how direction is set for corporate governance and enterprise management in the shareholder-value universe.

TSR comes in two versions - absolute and relative. Absolute TSR is about shareholder reward in individual companies. Relative TSR, on the other hand, is a comparative value. Relative TSR compares investment returns for a company against peer companies over a specific time period. In effect, the device Enron adopted in its terminal stages - namely, use of relative share price to measure executive performance - has now become standard and is the single largest metric for executive performance, as shown below. In its present form, the measure includes share price movements as well as shareholder payouts.

Equilar (2017), a leading corporate governance services provider, reported the following trends in Canada and the US within the metrics that leading companies use in executive bonus plans (Table 1.2). The top-ranking metric for executive bonuses is TSR, more precisely relative TSR. 
The following are some important takeaways from the data provided by Equilar (2017).

- Relative TSR was the most prominent performance metric for CEOs, used by 37.5 percent of Canadian companies included in the S\&P/TSX Composite Index and a somewhat higher percentage of US companies in the S\&P Index (45.6).

- A much smaller percentage of companies also used absolute, or independent, TSR as a criterion. When this is added to relative TSR, the aggregate percentage of TSR rises further (42.9 in Canada and 50.8 in the US).

- Return on capital (ROC) and EPS were the other commonly used performance metrics. Canadian percentages for ROC and EPS (11.9 and 9.2, respectively) were markedly lower than in the US (22.8 and 23.6, respectively).

- Significantly, a very small percentage of Canadian companies (5.4) also applied non-financial considerations. There is no information on what these considerations are. And there is apparently no similar practice among US companies to include non-financial criteria for the award of bonuses to executives.

The trends are clear. Shareholder value continues to be the influential mantra in both the US and Canada. They affirm the dominance of shareholder-centric governance. The top metrics for executive bonuses - TSR, ROC and EPS - are purely financial and encourage a focus on the immediate future. In essence, companies adopt the goal of shareholder value and strive to deliver, as best as they can.

Revenue, as a measure of executive performance, was more common in the US (18 percent vis-à-vis 4.3 percent in Canada). Revenue is about growth in business. Equilar (2019) found that bonus plans did not generally use revenue as an independent or standalone metric, but in conjunction with other criteria, presumably profitability. This is hard to fault. Growth in itself has little value, unless it is also viable and sustainable.

In any case the measures applied to evaluate the performance of executives for the award of bonuses, discussed above, are overwhelmingly financial. There are no meaningful criteria that can persuade executives to treat non-shareholder groups (employees, environment, consumers, communities) in a fair and responsible manner. On the contrary, the metrics in use would strengthen cost-saving, profit-maximizing tendencies (that generally harm non-shareholders). In Canada, as noted, a small percentage of companies (5.4) also included non-financial considerations but this is clearly too small a subset to be of any significance. 
The most commonly used metrics, in addition to being financial, also focus on the short term. Experience shows they tend to strengthen the profit maximization principle and promote shareholder value, and thereby also benefit executives who earn bonuses. The arrangement places other stakeholders at a serious disadvantage. To maximize profits, companies tend to economize on expenses that are vital for non-shareholder groups (e.g. wage increases for employees and investments in operational and environmental safety).

Analyzing the executive bonus plans of US S\&P companies for 2017, Equilar (2019) reported that 87 percent of the performance awards granted to executive officers had three-year performance periods. Considering the longstanding complaints about short-termism (obsession with quarterly earnings and impact on share price) (see for example, Mitchell 2001) and the advocacy of more long-term approaches to governance, a question is whether the three-year time horizon reported by Equilar (2019) represents an improvement.

Three-year terms for executive bonus plans have been around for a long time. Enron's 1994 contract with Kenneth Lay, discussed earlier, had a three-year timeframe for the award of a bonus (Vasudev 2008). Equilar (2019), reflecting current practice, consistently uses the title "Long-Term Incentive Plans (LTIP)" in referring to executive bonus plans. The validity of the LTIP rhetoric is questionable considering three-year terms for bonus plans have been the norm for over two decades, including in Enron. Three-year terms can hardly be viewed as a meaningful response to complaints about corporate short-termism or as instruments for switching to longer time horizons for executive bonus plans.

\section{c Share price fixation - recent evidence}

The evidence is that the preoccupation with share prices continues unchecked. Two prominent examples are GE and Uber, the former an ancient company struggling to reinvent itself and the latter a tech start-up that whetted investor appetite in recent years. The context was different in the two companies, but not the method.

GE, the faltering giant founded by Thomas Alva Edison, inducted Larry Culp as CEO in 2018. Reflecting the decline in GE share prices in recent years, Culp's contract was "stock-heavy" (Sheetz 2018). The aim was to get Culp to work for share price recovery. As an incentive, the contract linked his bonus to a rise in share price.

- If GE shares rose 50 percent, Culp would receive an equity reward of 2.5 million shares at about US\$ 18.60 a share (about US\$ 47 million).

- If the shares rose 150 percent, Culp would be given 7.5 million shares at US\$ 31 a share (about US\$ 233 million). 
Incidentally, GE was among the top ten companies Lazonick (2014) identified for shareholder payouts. During 2003-2012, it paid out US\$ 132 billion to shareholders. This represented 81 percent of the net income it earned during the period.

Uber, the ride-hailing company that is also hailed for its "disruptive" impact on taxicabs, had attracted large speculative investments, pre-IPO. Investors, quite obviously, hoped to ride on a "big-bang" listing of Uber shares. The company, founded in 2009, has been controversial from the early stages and its founder-CEO, Travis Kalanick, had to resign. Finally, Uber went public in April 2019. Melin (2019) reported that Uber's new CEO inducted in 2017 and his top team would qualify for (undisclosed) huge bonuses if the company's valuation crossed US\$ 120 billion on listing.

The nature of the contract GE and Uber concluded with their CEOs and the incentives mechanism that were adopted underscore the speculative feature in share prices. Arguably, an important driver of share price fixation and stock market-centric approaches is the possibility of windfalls and the theoretically infinite financial gains that the market holds for investors in common shares. This is an important foundation of shareholder value. In effect, shareholder value has institutionalized unbridled speculation in the governance of vital socioeconomic institutions. The broad outcomes in the age of shareholder value are surveyed in the next two chapters. 